Article

\title{
Evaluation of M-Payment Technology and Sectoral System Innovation-A Comparative Study of UK and Indian Models
}

\author{
Heather Webb ${ }^{1,+}{ }^{\mathbb{C}}$, Shubo Liu ${ }^{2,+}$ and Min-Ren Yan ${ }^{3, *}$ \\ 1 Higher Colleges of Technology, Dubai Men's College, Dubai 00000, UAE; hwebb@hct.ac.ae \\ 2 Business School, Central University of Finance and Economics, Beijing 102200, China; liushubo@cufe.edu.cn \\ 3 College of Business, Chinese Culture University, Taipei 11114, Taiwan \\ * Correspondence: ymr3@faculty.pccu.edu.tw \\ + The first two authors contribute equally to this project, they are co-first author.
}

Received: 8 September 2019; Accepted: 30 October 2019; Published: 4 November 2019

\begin{abstract}
The paper constructs a sectoral system of innovation model specifically for the mobile payments (m-payments) sector. Both the UK and Indian sectoral system of innovation were studied in regards of the actors involved in providing the m-payment service with an emphasis on emergent business models. We integrated open innovation and Ogle's ideas into our model and demonstrated the importance of active agency in shaping innovation systems, for example in leveraging existing social networks. The research draws upon original interviews with companies and regulators in both India and the UK. Our overall conclusion is that the m-payments sectoral system of innovation in India is more customer-oriented and far-reaching as compared to the practices in UK. It concludes that no matter the context, the importance of integrating firms' activity into integrated service systems in demand-driven innovation is key for success.
\end{abstract}

Keywords: sectoral system of innovation; mobile payments; India; active agency; business model; open innovation

\section{Introduction}

By adopting state-of-the-art technologies, developing countries avoid the costs of unnecessary infrastructure or learning curves by moving directly to high effectiveness levels; possibly adapting the technology to a new context, and in some cases, such as frugal innovation, creating better value products. The alternative scenario may be developing countries inwardly, transferring advanced technologies that prove ineffective as social and physical infrastructures prove incapable of supporting their use [1]. This paper explores mobile payments services (m-payments), in comparing the sectorial system of innovation in the developed country of the UK and contrasting it with the developing country of India.

Our argument is that despite the technological superiority of UK infrastructure, some aspects of the Indian m-payments sectoral system of innovation (SSI) are more innovative than the UK because of leveraging existing social networks and agreeing system-wide standards. This is significant since Gartner [2] forecasts huge global growth in m-payments for millions of users.

In recent years, the unbanked UK population has halved from 2.7 million to 1.1 million. Now, $97 \%$ of adults are enjoying formal institutional banking and near universal mobile ownership; still, $44 \%$ of people with contactless Near Field Communication (NFC) payment options fail to use them, and only recently have UK banks begun offering person-to-person (P2P) transfers. The UK m-payments SSI is fragmented with banks, telecommunications (TeleCos) companies and retailers vying to impose standards. 
The effectiveness of India's m-payments SSI is highly significant since banking levels are lower than other developing countries with $35 \%$ of adults having an account at a formal financial institution, $55 \%$ having deposit accounts and only $8 \%$ having a formal loan [3]; thus, a precursor to economic inclusion. As experiences in Ghana [4] and China [5] demonstrate, conducting business via m-payments accelerates small business development, yet India has 70 mobile phone subscriptions per 100 people, however, only $4 \%$ of Indians conduct m-payment transactions and $47 \%$ of households have no mobile device, despite local smartphone manufactures such as Micromax and Karbonn rapidly reducing device costs [6]. An effective m-payments SSI promises social inclusion and economic development, while avoiding high transaction costs and the risks of physically sending hard currency.

The challenge facing both m-payments SSIs is to realize the potential advantage to users such as time and place independence, availability, possibilities for remote purchases and queue avoidance $[7,8]$. The m-payments SSI can overcome barriers such as premium pricing of the payments, complexity of payment procedures, a lack of widespread merchant acceptance and perceived risks [9] including security, confidentiality, data integrity, authentication and non-repudiation and [10] guaranteed anonymity and privacy.

To compare UK and Indian m-payments SSIs we provide a new multi-level SSI m-payments processual framework that focuses on firms as active agents occupying ideas space [11] to emphasize active agency. We focus especially on emergent business models as a measure of innovativeness, which we apply to interpret data from twenty-seven interviews with m-payments agents in the UK and India (see Appendix A). From this comparison, one can conclude that in many ways the Indian SSI is more innovative, and parts of it more likely to internationalize. We address two research questions: how does the m-payments SSI shape business models; and secondly, what are the drivers of innovation in the UK and India m-payments SSI? In addition, we comment upon prospects for the sector in each country in global markets and their possibilities or ability to internationalize. In the following section, we define SSI, business models and mobile payment system. The next section is the methodology while Section 3 presents the findings. Section 4 is the discussion followed by Section 5 , which is the conclusion and mentions future research.

\section{Literature Review}

Beginning with a review of SSI and introducing the concept of ideas space as a way of combating the danger of determinism in systems theory, this review proceeds to discuss business models. We argue that as open innovation and innovation systems may perhaps alter business models. We argue that as open innovation and innovation systems may perhaps alter business models, a sustainable surplus is enabled as the parameters of SSIs alter.

\subsection{Sectorial Systems of Innovation (SSI)}

While Breschi and Malerba [12] define SSIs as a supply side technological system, Geels [13] develops the notion of SSIs to include both supply and demand institutions with social and technical parameters such as markets, user-stakeholders, university-industry links and sources of risk capital. Therefore, these parameters, alongside research and development (R\&D) become change drivers, while the footprint and governances of each SSI depends upon context and spatial reach.

All systems' approaches face challenges including drawing system boundaries, selecting agents and establishing causal relationships. Breschi and Malerba [12] argue, by the actions of people, grounding particular moments of technological and market opportunity is the best protection against systems being deterministic or merely descriptive. Therefore, people play an important part in SSI innovation: they are not an abstract of a socio-technical system [14], but rather SSIs feature active agency, including the political influences found in varieties of capitalism [15,16].

SSIs governances are contingent upon heritage and opportunities: each SSI features specific structures and modes of operation, in particular social, market and temporal contexts where interaction between SSIs creates new opportunities for firms. In the case of m-payments, banking regulation, 
security protocols, Internet connectivity and mobile devices are important. For Scott [17] types of rule-making powers are important: regulative (formal), normative and cognitive (intellectual paradigms), especially if SSIs conflict or conflict occurs within the SSI; for example, between networks, banks, and platform and application providers. Governances set boundaries in which firms, individuals and organizations operate, what Kay [18] refers to as "disciplined pluralism". Indeed, as SSIs innovate, their composition and governances are likely to enter phase transitions [19] towards embracing new technologies and markets.

With their genealogy in Hughes' [20] technical networks and Malerba's [21] technological systems, SSIs can be interpreted as underplaying the importance of innovators and their learning. However, we take a social learning perspective [22] insisting that individual cognition, followed by distributed cognition [23] is essential to create or make sense of knowledge. Firms and agents in SSIs thus occupy ideas space [1], similar to Bourdieu's [24] habitus in which individuals make new combinations of knowledge, yet within the paradigm of exploitability set by the SSI, such as user acceptability, technical complementarily.

Figure 1 represents an m-payments SSI framework to map and analyze the m-payments sectors in the UK and India. Linking the supply and demand aspects of the SSI is habitus, which is shorthand for particularly British or Indian cultures and ways-of-working aligning production and consumption. Supporting and shaping the SSI is an array of supply and demand, social and technical factors: the more social to the left and more technical to the right. The demand side is shown to begin with business-to-business (B2B) and business-to-commerce (B2C) markets, their size and trajectories, the availability of professional services such as accountancy, design, marketing, lawyers, and competitor firms and the intensity of competition. Change drivers suggest NSI and macro-economic factors influence the SSI.

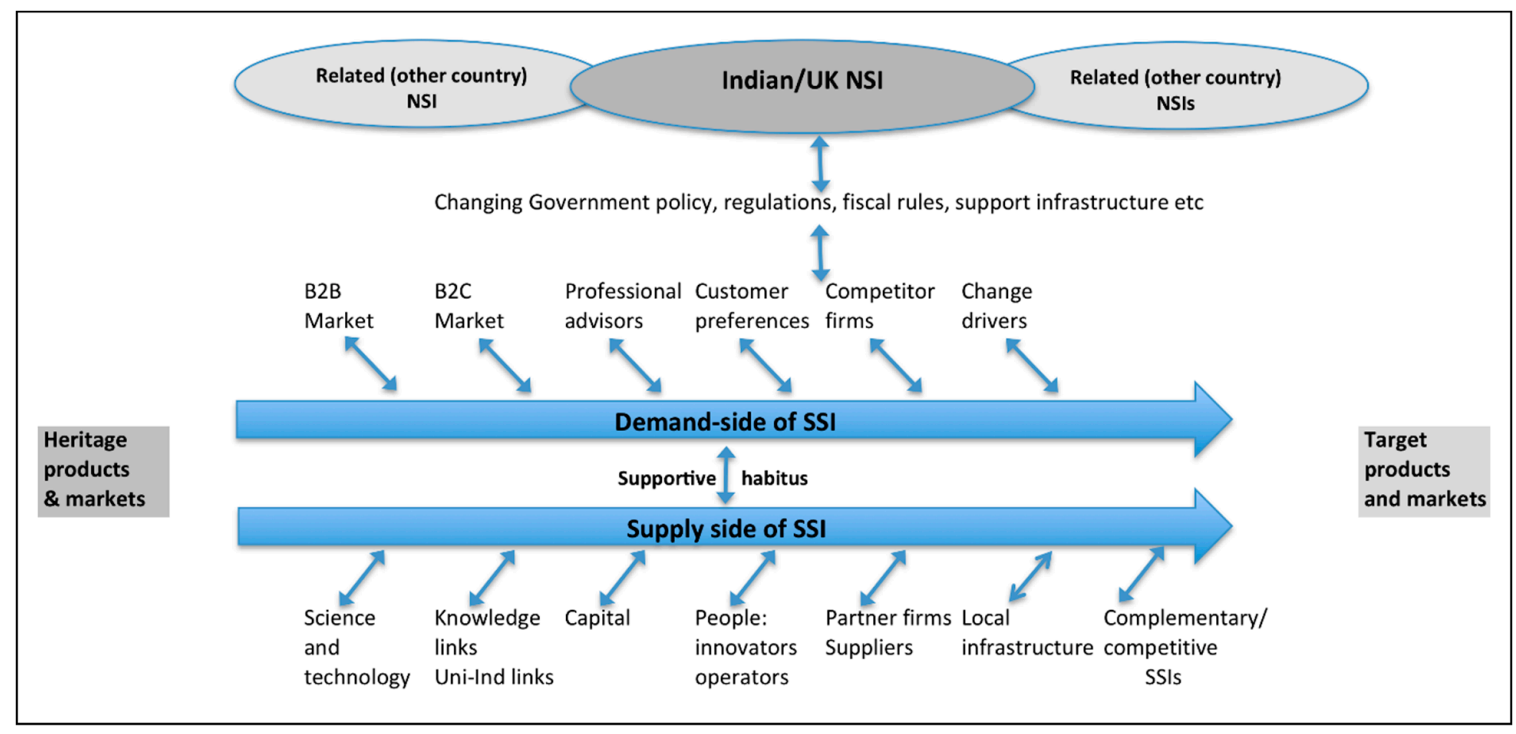

Figure 1. Conceptual representation of sectoral system of innovation (SSI).

Figure 2 below combines aspects of SSI and how ideas space can be relevant for future scenarios of m-payments. The figure begins with a simple m-payment solution where institutional voids and knowledge understanding create a specific market. A market will create different consumer segments where regulations are instituted. At this point, a firm does not know if the service is profitable, thus, firms have to decide price and cost choices as well as what can the consumer afford. It becomes a risk for all firms involved in m-payments. Therefore, in taking the concept of ideas space, firms, at this point, can disrupt, change technological and market opportunities, and/or continuing learning with knowledge exchanges. However, at the end, it is the hope that the firm will create a sustainable, profitable business. 


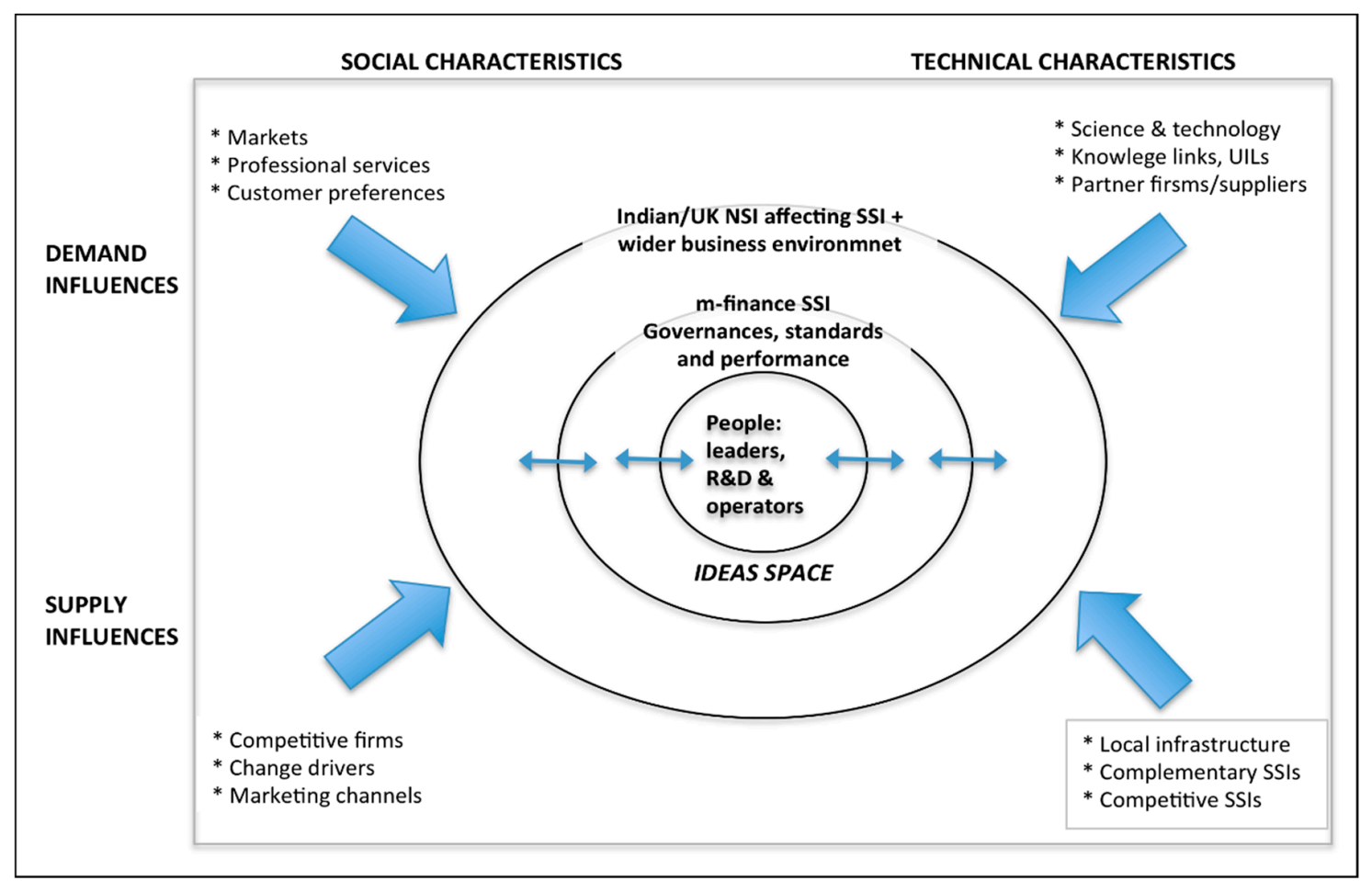

Figure 2. Institutions and components with their inter-relationships constituting the m-payments SSI.

The supply side of Figure 2 begins with the science and technology available to the SSI, followed by the sources of this knowledge and the SSI's ability therefore to exploit the knowledge. Particularly important here are university-industry links; this sector is at the cutting edge of science-technology development. Also important, as Herrmann and Peine [25] stress, are the right mix of leadership, scientific labor and operator level labor, and the supply of resources such as capital in all its forms, including state aid. Cross-fertilization of ideas between foreign direct investors (FDIs) and indigenous firms, either via supply contracts or staff mobility [26] is shown to be significant. Thus, the issue of evolving standards suitable for British/Indian and international markets and the processes of arriving at decisions on standards, is of crucial interest to the SSI and one of its important interactions with its own and other NSIs.

Whilst Geels' [13] SSI model emphasizes their dynamic nature and interaction with National System of Innovation (NSI) and market environments, yet remains an abstract mapping tool, alternatively, Figure 2 represents conceptually a snapshot of a SSI, capturing its demand and supply influences and characteristics that are both social and technical. Of course, these are not watertight compartments, all SSI feature trade-offs, tensions, alignments and compromises between constituent parts and trajectories. At the center of the SSI are people (leaders, researchers, decision-takers and operators) occupying the ideas space envisioning and directing SSIs. Arrows between the ideas space, SSI, national systems of innovation (NSI) and business environment indicate how these systems mutually shape, influence, constrain and enable the other. In each quadrant, examples are given of factors enabling or disabling the ability of the SSI to innovate drawn from SSI literature including Geels [13].

Having reviewed research literature on SSIs, this section has criticized some formulations of innovations systems as deterministic and inadequately theorizing agency within institutional structures. Figures 1 and 2 adapt the SSI framework to centrally feature human agency in the form of sector leaders, researchers, decision-takers and operatives, located in a specific business and cultural context-the habitus in which m-payments is being innovated in the UK and India. 


\subsection{Business Models}

Schumpeter [27] argues that each creative gale of destruction is accompanied by, and in turn, supports innovative business models. Thus, innovative business models need to create demand by converging technology and focusing on the future customer even though there is no customer currently [28]. Business models are an important aspect of the evolutionary theory of the firm [29]. A business model is a schematic, simplified representation of choices around how businesses create and distribute value amongst stakeholders as well as how it evolves its model. At the heart of a business model are costs, sales/price and margins, thus, predicting profitability. Externally represented to customers in the form of a perceived value proposition, the business model is the internal (detailed) encapsulation of a business plan, including service (or product) touch-points, market, operations, capital, risk and people. Nor are there unchanging recipes since successful business models will evolve with environments and opportunities that emerge, recombining the application of learning as technology and markets change. Since the majority of business models, and businesses, now follow a service-dominant logic [30,31], service touch-points [32] and user experiences will prominently feature in effective business models, as distinct from the goods-dominant logic found in much of the literature and in Amit and Zott's [33] discussion of e-commerce models.

Business models are best re-evaluated and altered in the light of changing technologies and market opportunities; in short as business leaders learn. The business model has advanced into the open business model; defined as a new combination between technology and a market guided by entrepreneurs [34,35]. For open innovation business models, it is guided by start-ups and SMEs; whereas the closed innovation business models are developed from big businesses [36]. For a globalized market, any firms' business model needs to innovate quickly in order to be competitive [34]. The danger, as Amit and Zott [33] point out, is that once choices are exercised, they become a logic or mindset [37] which inertia or insularity or perceived success make difficult to alter; ties that bind, also blind [38]. Chesbrough [39] favors this dynamic view of business models arguing that dominant logic can narrow scanning and search for new solutions. McGrath [40] suggests a discovery approach-i.e., evolving business models. It is on these change processes that this research focuses on as such business leaders in the UK and India are responding in different ways to similar changing opportunities. This differs from Demil and Lecocq's [41] conclusion that business models can be static or transformative, in that on-going businesses require both stability and change to prosper and may for periods utilize multiple business models [42] provided levels of learning are high, customers can be segregated and autonomous delivery teams empowered.

\subsection{The Nature of M-Payments}

Our focus is on innovation in m-payments, rather than the wider eco-system including $\mathrm{m}$-commerce and m-banking discussed by Turban et al. [43] and Laukkanen [44]. M-payment is more narrowly defined as paying for goods and/or services: the recipient of the payment as Karnouskos and Fokus [45] and Dahlberg et al. [46] make clear, is a seller, not necessarily a bank. The payment may be from stored value (e-wallet) often accessing other loyalty of currency exchange benefits using cloud or near-field communication (NFC) connectivity or other stored information such as identity, insurance or ticketing data facilitated by platforms. M-payments examples include Ten-cent, Weibo, Google, PayPal, Nokia and MasterCard. Issues associated with m-payments include: the lack of a global standard, at times even lack of national standards, in the payments ecosystems; issues of cross-country currency exchange rates and of course trust, security and privacy.

The wider m-finance eco-system (Figure 3) is fragmented, unstable and subject to disruption. For example, in m-banking new entrants from the tech industry such as Google and PayPal are tempting clients with convenient mobile apps. These actors are not straddled with the legacy costs of banks. Figure 3 presents a snapshot of the differentiated actors in the ecosystem for the UK. Mobile ecommerce, more commonly known as m-commerce, is online transactions that use wireless electronic devices such 
as laptops, tablets or mobile phones. These devices communicate with networks in order to exchange or transact the payment.

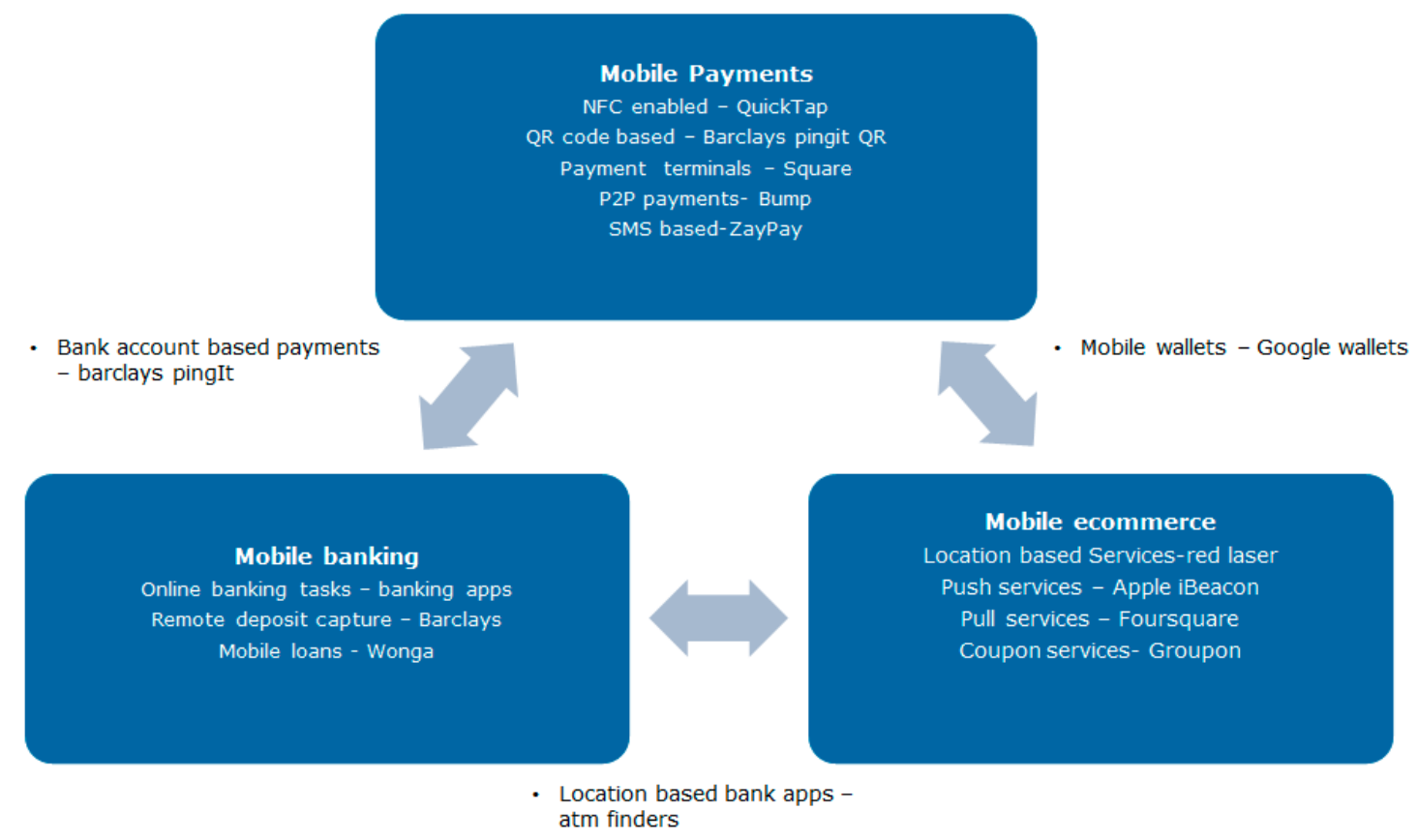

Figure 3. Mobile payments services (m-payments) ecosystem of UK.

\section{Methodology}

This research is an exploratory inquiry; exploratory because it relates to an emergent sector in which innovation patterns and processes are experimental and provisional. This is essentially qualitative research relying upon semi-structured interviews and masses of secondary data interpreted using basic statistical techniques and presented using qualitative statistics. This research is inductive [47] and interpretive in order to understand social facts whilst acknowledging they are not out there awaiting discovery. Thus, social facts require social construction as Rabinow and Sullivan [48] insist. This is a process that Yanow [49] calls making meaning or having assembled facts. These facts are given a structure in order to draw conclusions; the persuasiveness and generalizability of which are for others to decide and the business impact to be dictated over time.

The research asks forward-looking social and business questions (change drivers, nature of innovation, global leadership), therefore as Hewitt-Taylor [50] and Ambert et al. [51] argue, one cannot simply extrapolate from gathered data. Positivist projections from a small evidence base are a recipe for business disaster [52]. Nonetheless, difficult questions about the future of an emerging technology cannot be answered through interpretation [53]. Therefore, the research is primarily interpretive, asking as Saunders et al. [54] suggest, "why" and "how" rather than "what" questions.

We take a case study approach, since as Saunders et al. [54] note, provided the cases are rich, they reveal the big narratives and details of causal relationships between agents and with different levels of the environment. Multiple cases such as the UK SSIs and Indian, allow for comparison [55].

One of our co-authors conducted 27 semi-structured interviews in the UK and India, selecting high-level interviewees (policy or strategy makers) influencing m-payments innovation. Interviewees heralded from major network providers, software developers, banks (RBS and Barclays in the UK), systems integrators, senior Government officials and solutions providers. These included Vice Presidents of Banks, the Department Head for banking inclusion in India, the Deputy General Manager of a major Indian Bank, and the CEOs of seven software, solutions and systems integrator companies. Most interviewees choose anonymity, only those respondents giving express permission are cited and then only by position, not name. 
Prior to semi-structured interviews, we rigorously desk-researched the firms, their products and any public documentation related to the firms' products or services. Interviews were recorded and transcribed, then coded and themed, the themes from which structure our case study. Data is presented in the form of two case studies and analyzed using Nvivo in-case, then cross-case and finally triangulating with previous research: a thematic analysis.

As Eisenhardt [55] argues, it is important to allow the unique patterns of each case to emerge before investigators push to generalize patterns across case; it gives investigators a rich familiarity with each case which, in turn, accelerates cross-case comparison. Our analytical rigor rests on three approaches. Firstly, we carefully coded from the cases, using terms such as innovation, learning, customers, competition, technology; identifying key nodes, meanings and patterns. Secondly, following Eisenhardt [55] and Hartley [56] we triangulate carefully with previous theorizations of $m$-finance innovation and cross-country comparisons As Yin [57] suggests, we compare data with the related theoretical propositions that led to the case study investigation. Consequently, the data was analyzed using a clear conceptual framework, topic guide and reviewed literature on innovation (Figure 3). This enables us to contrast the meaning and practice of innovation in $\mathrm{m}$-finance compared to wider conceptualizations of innovation: building new theory from the cases [58]. Our third protection approach to analysis has been a long period of collective sense-making around the ideas, actions and events that we record, during which each of us has evolved new interpretations.

We share Frederickson's [59] aim in cross-case analysis of creating middle-range theory, Llewelyn's [60] idea of context-bound conceptualizations by unpicking two complex contexts and then reintegrating them in a contextualized analysis [61,62]. Following Pauwels and Matthyssens [63] our cross-case analysis is characterized by theoretical sampling, triangulation, analytical generalization and pattern-matching logic and a single validation route through concurrence and iteration. We closely align also with Gummesson [64] who argues that generalization from such research is possible provided the results are re-contextualized echoing Elliott's [65] idea that trustworthiness rather than internal/external validity makes research worthy of impact.

\section{Framework Development}

In arriving at the themes, the SSI framework for m-finance was used to calculate the actual drivers of the innovation. Additionally, coded patterns started to arise where then it was integrated in succession of where the firms fell in the innovation process.

One of the main drivers of innovation is the supply. Throughout the data collection process, numerous firms were interviewed who either have the final relationship with the end-user or have relationships with other suppliers within the service chain. Another driver is the demand side of the innovation process, which is not necessarily created from the end-users, but by the suppliers themselves. In this case, it is the customers and consumers of the overall mobile payment system which include mobile banking and digital wallet. For each firm profiled in the next section, their customers are different since each firm provides an aspect of the overall service process. Majority of the banks, their consumers are the end user, whereas majority of the technology and software firms, their consumers are other merchants or banks or telcos. It all depends on the business model the firm utilizes as well as what industry the firm is from. Additionally, customers will depend on what aspect of the mobile payment ecosystem a firm utilizes.

Additionally, regulation theme will be discussed since regulation in both India and the UK are different, which causes the innovation process to be different even if demand and supply are very similar. Banks and other financial institutions are, at times, constrained by regulation, whereas other players in the ecosystem like telcos are not necessarily limited to the same regulations as financial institutions. For both India and the UK, approaches to regulation have been dissimilar. India takes a more conservative approach with the conclusions that consumers and merchants need to be protected. Although the population of the two countries are vastly different, India lacks a national system of identity cards, which effects the aspects of regulation as well as the innovation process. For the UK, 
regulation is more relaxed since there is no specific mobile payment framework. Regulation sits across a variety of bodies and rarely do these government bodies specifically have a focus on mobile payment systems. However, there is general guidance about how to communicate with customers and merchants. Yet, the relationship between regulation and policies with innovation is complex as well as dynamic.

The last theme in the driver of innovation is technology. Specifically, communication technology has been a core aspect of the innovation process and what creates the service as being innovative and new. As the ecosystem has grown in both developed and emerging economies, technologies have advanced and the financial industry is witnessing new entrants of intermediaries. Firms, however, have different aspects of the applications at their disposal for interacting with their customers. Yet, no matter the country, new technology can be limited and there has to be a distinction of mobile payment usage. When being specific in discussion technologies, for mobile banking these are: SMS text, mobile browser, custom applications. For mobile payment technologies: NFC companion devices embedded NFC, SMS text and voice. These technologies are either specific for mobile payment system or are used in both banking and non-banking service. However, payment systems can be bundled together with other processes which can create confusion and slows the development of usage. Each profile case will discuss the technology aspect of their service process.

Table 1 presents the variables in our analytical framework, bringing together the dimensions of m-payments SSI (Figure 4) with the business model choices facing the m-payments firm. Note the firm is an actor in a m-payments value-system; depending on power and value-flows [66] in any particular SSI the key actor may be a bank, network, ISP, platform, application and/or device manufacturer; the firm may be indigenous (targeting international and/or local markets), inward investor or some form of joint-venture. Solution service offers may be narrowly focused or cross the spread of 5-M's: movement; moment; me (communities); money and/or machines (device fusion) suggested by Ahonen [67]. One should draw attention to fifteen key variables influencing innovation (numbered in small circles) and detailed in Figure 4. The assumption is that Clemons [68] is correct in arguing that advertising plays little role in effective m-payments business models since customer neither trust, want or need unwanted referrals, especially when deliberately misdirected to wanted sites.

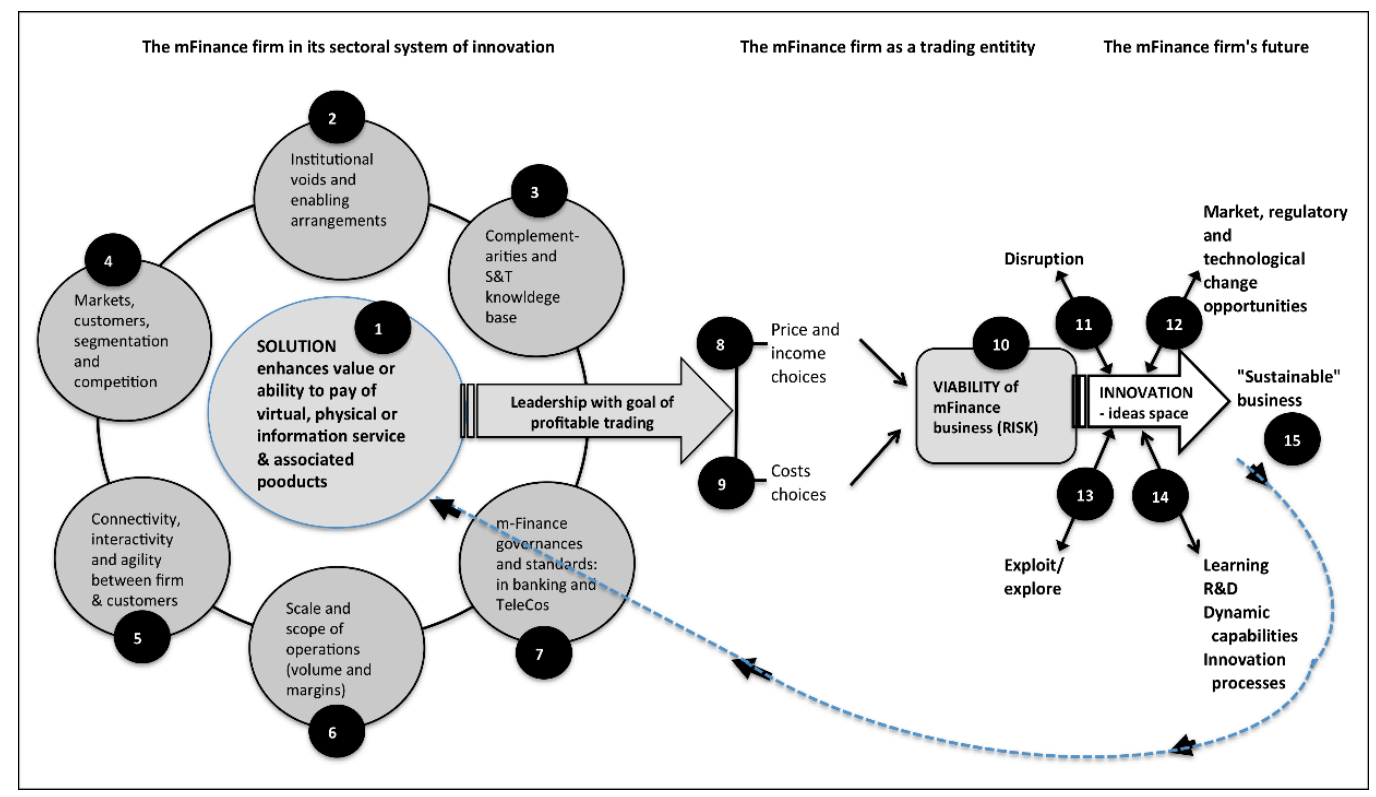

Figure 4. The m-payments firm trading in a SSI.

For the actual payment process, there are specific stages where the business model is affected at every point according to Ondrus and Lyytinen [69]. The first stage is that strategic, inter-organizational alliances need to be formed. These alliances include the network operators and financial institutions 
forge partnerships to facilitate the delivery solution. As a unit, this is what Ondrus and Lyytinen [69] term the newcomer who must proactively forge relationships with merchants and business intermediaries to strengthen its competitive position in the marketplace. They then must act as insurgents to generate awareness, attract customers and gain market share. The last process is where these novices must forge relationships with device and infrastructure manufacturers, which are interoperable and permit scalable payment solutions [69]. In opposing the view of Whitley [70] that national markets can be differentiated as liberal or coordinated market economies, it seems therefore meaningful to ask if Indian or UK based firms will be most successful in international m-payments markets.

Table 1. Fifteen variables in analytical framework.

\begin{tabular}{|c|c|}
\hline 1 & $\begin{array}{l}\text { Solution: the service offer (virtual, physical or information products) such as P2P payment, or } \\
\text { payment for goods: note the connection to business leadership }\end{array}$ \\
\hline 2 & $\begin{array}{l}\text { Institutional thickness or institutional voids enabling/inhibiting } \mathrm{m} \text {-finance, such as the availability of a } \\
\text { banking network to target customers }\end{array}$ \\
\hline 3 & $\begin{array}{l}\text { Complementarity arrangements to } \mathrm{m} \text {-finance such as Internet penetration, } 3 \mathrm{G} \text { availability and } \\
\text { connections into the relevant science and technology base }\end{array}$ \\
\hline 4 & $\begin{array}{l}\text { Customers, how they segment (high value or low-cost business models) and how the firm competes } \\
\text { with competitors - its strategic USPs }\end{array}$ \\
\hline 5 & Basic connectivity, user-provider interactivity and the agility of the firm to respond to opportunities \\
\hline 6 & Scale and scope: range of services, volume of target provision \\
\hline 7 & $\begin{array}{l}\text { Key governances and standards impacting on m-finance design and delivery, banking and TeleCos } \\
\text { governances and operations }\end{array}$ \\
\hline 8 & Price/income choices such as ARPU maximization or high-volume low margin services \\
\hline 9 & Cost, cost-sensitivity of the firm and who bears cost within the ecosystem \\
\hline 10 & Viability of business model: can the firm trade at a profit and who is bearing what risk? \\
\hline 11 & Over time, is it likely that the business model and firm can be disrupted? \\
\hline 12 & $\begin{array}{l}\text { Over time, are changes in markets, technology or regulation opportunities or threats; such as the } \\
\text { impact of the cloud? }\end{array}$ \\
\hline 13 & Over time, should the firm's strategy be exploitation or exploration? \\
\hline 14 & $\begin{array}{l}\text { Over time, is the firm actively learning, exploiting R\&D and evolving dynamic capabilities to remain } \\
\text { competitive? }\end{array}$ \\
\hline 15 & $\begin{array}{l}\text { Over time, is the firm capable of the sustained innovation necessary to be a sustainable business, } \\
\text { including altering its business model? }\end{array}$ \\
\hline
\end{tabular}

\section{Findings}

\subsection{The UK M-Payments Sectoral Systems of Innovation}

Table 2 uses Figure 4 and Table 1 to illustrate the key parameters of the UK m-payments SSI.

\subsubsection{Wide Range of Agents}

Actors in the UK's m-payments SSI ideas space are far more varied than in India's case. In the UK, it includes banks and other actors such as retailers and other "brands" providing either full-range mobile financial services (Sainsbury's; Marks and Spencer) or e-wallet apps, often with NFC capability, such as BP, transport, café-chains and parking companies. The ideas space is occupied by in-house and contract apps developers who sell or partner their technology to branded service providers, who often in turn cooperate with banks for back-office systems. Banks such as LBG are prone to partnerships; others such as RBS and Barclays operate only proprietary systems. However, UK software CEO alluded to the fact that: 
One of the biggest challenges of mobile payments is that it often addresses low value payments, also meaning low revenue per transactions. If you want a sustainable business model, you then need to process higher volumes of transactions, more transactions, less revenue per transaction.

Table 2. Key parameters of the UK m-payments SSI.

Solution: all of the UK has wired Internet coverage, those areas without mobile network coverage are 1 isolated rural settlements, the quality of the connectivity varies. $99.6 \%$ of the population can access at least $2 \mathrm{G}$ and access (sometimes slowly) a wide range of m-payment services.

Institutional thickness: personal financial services are more highly regulated than apps and mobile

2 connectivity. Institutional arrangements, such as the payment of wages and benefits enforces bank account usage. Institutions drive innovation targeting higher-end customers.

Complementarily arrangements to m-payment: the UK is globally competitive in Internet security,

3 apps development and personal (and investment) financial services innovation as the Barclays case demonstrates. There is a close relationship between industry actor R\&D and university research bases around Informatics products such as apps.

UK banks have low or non-existent charges, however, charges are high for additional services (such as overdrafts); banks choose their customers often by de-marketing poorer segments of society: high income individual and businesses are the banks preferred customers, for whom they provide a wide range of services, including traditionally non-Bank services.

\begin{tabular}{ll}
\hline $\mathbf{5}$ & $\begin{array}{l}\text { Basic connectivity is high; most (3G) users can access highly interactive m-finance services via } \\
\text { m-Internet or apps. M-payments are a major area of competition between banks e.g., RBS's GetCash } \\
\text { app. }\end{array}$ \\
\hline $\mathbf{6}$ & $\begin{array}{l}\text { 25\% of the UK m-Internet users access m-finance services, often via dedicated Bank app. Scope of } \\
\text { services varies: the Barclays case indicates how m-banking is seen as competitive advantage. }\end{array}$ \\
\hline $\mathbf{7}$ & $\begin{array}{l}\text { Key governances and standards: while banks are regulated, non-bank organizations are opening } \\
\text { banks (retailors), acting as banks (iTunes) or offering C2B payment services (including telcos). }\end{array}$ \\
\hline $\mathbf{8}$ & $\begin{array}{l}\text { Both banks and telcos compete for higher-value customers meaning those using a wider range of } \\
\text { paid-for services. }\end{array}$ \\
\hline $\mathbf{9}$ & $\begin{array}{l}\text { UK banks and telcos are highly profitable firms squeeze costs by automating services } \\
\mathbf{1 0}\end{array}$ \\
$\begin{array}{l}\text { M-finance firms (including banks) and telcos minimize risk using techniques such as credit scoring } \\
\text { and high charges for some services, they trade profitably: risk are exogenous such as the banking } \\
\text { crises or over paying for network licenses. }\end{array}$ \\
\hline $\mathbf{1 1}$ & $\begin{array}{l}\text { Low cost alternatives (especially cloud-based_may disrupt, however, regulatory arrangements offer } \\
\text { protection to banks and telcos. }\end{array}$ \\
\hline $\mathbf{1 2}$ & $\begin{array}{l}\text { Low cost cloud services may disrupt, however, regulation changes would disrupt more. } \\
\mathbf{1 3}\end{array} \begin{array}{l}\text { Banks and telcos currently exploit their existing customer base by expanding service ranges (NFC, } \\
\text { PingIt), some organizations (Barclays) see innovation as giving competitive advantage. }\end{array}$ \\
\hline $\mathbf{1 4}$ & $\begin{array}{l}\text { R\&D (often university-based e.g., automated credit scoring and meta data analysis) supporting } \\
\text { automation drives down costs and increases margins. Telcos and banks seek to "bundle” wider ranges } \\
\text { of products, trading on brand. }\end{array}$ \\
\hline $\begin{array}{l}\text { Despite crises (banking, overpayment for licenses, market entry e.g., by retailers) the major firms in } \\
\text { the SSI survive profitably and internationalizing. }\end{array}$ \\
\hline
\end{tabular}

Many of RBS's apps created for m-banking and m-payment are not necessarily focused on profitability, but more so on customer engagement and forms of interaction with customers; which RBS views as a major part of its customer retention strategy. The cost of development, launch and the marketing is substantial for the bank; imitation and intellectual property rights theft are major concerns.

\subsubsection{Proprietary Systems}

Barclay's m-payment system, PingIt was launched in 2012, initially marketed to retail users; it is now being promoted to corporate and customers as a means of facilitating customer payments. Barclay's PingIt m-payment app supports systems more sophisticated than other UK banks because it 
enables P2P transfers using mobile phone numbers, via an e-wallet account, including to non-Barclays customers. As a Barclays Vice President says:

If you have to pay someone else you have to know their bank details, but Pingit will use your mobile phone number as a proxy for sort code or account details; you only need to know the mobile phone number using the app. Useful when you are with group of friends in paying your other friends instead of diving up a debit card. It does not matter what mobile company you are connected with, only that you have to have a bank account. So Pingit is a proxy.

PingIt is enabled by a private cloud rather than a website, plugging the app directing into a firewalled-protected environment. Pingit avoids rework via end-to-end processing and remains within the payments flow. This innovative process gives Barclays a product advantage over competitors.

\subsubsection{Dominant Banks}

As there is no general guidance on m-payment systems in the UK, services reference diverse regulations on m-payment and $\mathrm{m}$-banking; regulations relating to customer communication, data storage and banking fraud are detailed and onerous. The EU E-money 2000 Directive defines "electronic money" and introduces "electronic money institution" (EMI) as a special type of credit institution. This directive was the EU's first attempt to regulate and integrate EU electronic money banking standards. EMI's are not subject to the same regulations as other credit institutions facing lighter regulation: capital requirements, for example, are set lower to encourage non-banks to enter the e-money market. However, the directive failed to attract non-banks to become EMI's and after eight years of operation it was unable to achieve its objectives [71]. Since 2000, there had been relatively few licenses issued, and the size of the e-money market remains small for two reasons: limited consumer interest in e-payment instruments and the perceived failings of the EU regulatory regime.

The Second E-money Directive 2009 and the UK Electronic Money Regulations 2011 (EMR) was designed to encourage new entrants by imposing lower capital requirements and a lighter regulatory regime than the first directive. Entities that are not banks or building societies can become an authorized e-money issuer-small e-money issuers i.e., activities other than simply issuing e-money. EMIs are regulated by the Financial Services Authority (FSA), which the UK Government hopes will encourage new market entrants such as mobile phone operators.

The Payment Services Directive (2007/64/EC) (PSD), implemented in the UK as the Payment Services Regulations 2009, provides a legal framework for the operation of a single payment service market. This framework establishes a single license for payment service across the EU. The Manager of Emerging Technologies at a UK bank says she would prefer that all the agents involved in the service chain have to deal with the same regulatory framework:

Regulation impacts customers, in my opinion, potentially to a more convenient or innovative service. I guess it is also there to protect them, so I guess I have seen a lot of cases recently where banks have abused that and therefore regulation was required. From a bank's perspective then, to me it levels playing fields, so everyone is impacted by the same regulation. So, whilst it might impact your revenues slightly and impacts everyone's revenues, it is not as if it is a competitive advantage to be gained.

In the UK the Payments Council closely monitors developments in regulation and public policy at a national, European and international level and assess implications for payment systems, consumers, businesses and other organizations. When required, the payment council also coordinates the industry to implement regulatory change, such as the Payment Services Directive. The regulation of e-money is closely linked with the regulation of payment services regulated under the Payment Services Directive (2007/64/EC) and the Payment Services Regulations 2009 (SI 2009/209) (PSRs). Issue of e-money may include payment services including services that are unrelated to their e-money business. Thus, the Payments Council (PC) sets the strategy for UK payments and as the Cave (2009) report concludes, 
the banks dominate the Payment Councils, which fails to represent either the interests of customers or other businesses.

\subsubsection{Legacy Systems and Innovation}

The cost of altering legacy systems is more of an inhibitor to innovation than regulation. Spain's second-largest bank, BBVA believes that traditional banks will soon lose their monopoly on banking and need to take on the threats of technology companies such as Amazon or Google. These new entrants are not saddled by legacy costs of banks and have "cool" and convenient mobile applications (Economist 2014). UK TeleCos are now part of an EU-wide TeleCo network offering services across the Union and internationally, however, this is unlikely to protect their position as NFC and e-wallets replace the use of SIM cards as the best way to authorize identity.

\subsubsection{Social Impact}

Institutional arrangements in the UK address the unbanked issue by enforced banking (Payment of Wages Act and e-benefit payments); the one million unbanked in the UK are mainly single-parents, retired and unemployed where many of these will use m-payments app as e-wallets on PAYG mobiles. Fifty percent of UK mobiles are PAYG whereas in India it is almost $100 \%$ because of one negative result of which consumers are averse to $4 \mathrm{G}$ upgrading until their contracts expires.

\subsubsection{Intensity of Competition}

The UK m-payments SSI is intensely competitive: entry costs are low; especially so in Cloud-enabled e-wallets where discounting deals flourish particularly on cloud-based wallet platforms that readily overcome issues of hardware enablement for NFC since they use software-based technologies like the QR codes and line-skipping apps. Thus, they deliver a better value proposition: lower cost, easier registration and, for example, line-skipping apps allowing users to eliminate checkouts saving time. However, as The Manager of Emerging Technologies at a UK bank says:

Of course, I think most banks haven't even realized the opportunity for mobile banks, there are so many opportunities to make money. It is the traditional revenue streams that you can make money through, like I mentioned earlier; increasing sales, incremental sales, incremental transactions or incremental interactions with your brands as a bank, through mobile should lead to more and [so] those sorts of traditional revenue lines, these cost production revenue lines around moving people into mobile. Which by and large is the cheapest channel to service at the moment.

Competition is not just in providing the service with the end-user, but also the technology and solution development. Thus, the ecosystem is becoming overwhelming with competitive ranges of services that agents and consumers can be undecided as to which will be the better solution. This can lead to interoperability concerns especially as other innovative solutions are being developed.

\subsubsection{Governances}

Governances in the UK m-payments SSI have altered dramatically as new entrants challenge the monopoly position of the banks and TeleCos. There is now a multiplicity of standards and business models, which whilst favoring innovation, makes system-wide interoperability difficult. Yet, the Deputy General Manager at an Indian TeleCo says, "right now people are just, they're just focusing their attentions on trying to get the correct business model." Barclays P2P transfers heralds a breakthrough in the sense of meeting a KYC aspiration of paying for anything or transferring money to anywhere with the ease of sending an email or authorizing an NFC pin. Previous TeleCo business models deteriorated (voice ARPU, text-charging), UK TeleCo now relies on smart-phone data transfer by the 87 million contract holders ( $94 \%$ of the population), although this compensates in part for a ( $3 \% \mathrm{pa}$ ) decline in fixed-line contracts. There is no sustainable business model in the UK across the 
whole m-payments SSI: in the absence of institutional drivers for such a model, disruption remains possible. Yet, if the TeleCos and banks can agree on the governances for such a system, their primary position in the SSI governances may be restored, alternatively they may be disrupted by the entry of a major player (iTunes) or generalization of a (Barclays-type) product.

\subsection{The Indian M-Payments Sectoral Systems of Innovation}

Table 3 uses Figure 4 and Table 1 to illustrate the key parameters of the Indian m-payments SSI.

Table 3. Key parameters of the Indian m-payments SSI.

1 Solution: recognizing the cost effectiveness of $\mathrm{m}$-finance, the SSI is enabling the diffusion of mobile Internet-enables solutions providing financial inclusion for un-baned citizens.

Institutional thickness: while banking is strongly regulated and non-banks inhibited from providing

2 banking services, institutions support $m$-finance services to the poor in ways and at costs making them accessible: the institutions service as a social justice agenda.

Complementarily arrangements to m-mobile such as RBI regulations, NCPI infrastructure, TIBCO's data processing systems, for services such as Indusland Bank and Eko Financial Services, using physical infrastructures (retail outlets, the $2 \mathrm{G}$ telephone network).

Customers able to pay charges are served by 3G-enabled m-finance technologies and services

4 provided by the market. Bottom-of-the-pyramid customers can access simpler transaction services, using basic mobile devices leveraging either retail outlets (Eko) or the (numeric literacy) services of Indusland Bank.

Basic (2G) connectivity remains a challenge - around $20 \%$ of the population have a mobile, half have the access, many of the $50 \%$ are in rural areas outside mobile network reach. $2 \mathrm{G}$ networks provide sufficient connectivity for basic $\mathrm{m}$-finance services since firms are shaping services to align with the available technology and absence of banks.

Firms such as Indusland Bank and Eko are sustainable business provided the volume of transactions

6 is high and range of services narrow: it is likely that the scale of these services will continue to increase, with technical network reach a major constraint.

RBI strictly regulates banks; this obliges banks to support NPCI's infrastructure expansion IMPS

$7 \quad$ (affecting telcos and banks) and inhibits 'cherry picking' market strategies by banks or organizations that would otherwise enter the market (such as major retailers or brand names e.g., Infosys, Tata). Governances suit the social justice agenda.

8 Indian telcos operate on low ARPU; for the BoP segment this is especially so.

Advanced technologies (NFC, complex payments) are limited to 3G users, mainly in urban areas.

9 BoP services are cost sensitive and rely on scale economies and the intermediate/appropriate deployment of back-office technologies by firms such as TIBCO. Regulator pressure on telcos for network expansion imposes costs that they might otherwise choose not to endure.

Banks are protected from risks associate with services to BoP customers or businesses dealing with

10 BoP customers (TIBCO) by intermediaries such Indusland Bank and Eko, who in turn minimize risk using retailer bonds or bank underwriting.

\begin{tabular}{ll}
\hline $\mathbf{1 1}$ & Basic service models will wither as people become richer: not a short-term prospect. \\
\hline $\mathbf{1 2}$ & $\begin{array}{l}\text { The Cloud (TIBCO) is enhancing the BoP business models by helping contain the costs of high } \\
\text { transaction volumes. }\end{array}$ \\
\hline $\mathbf{1 3}$ & As the network reach expands, so too will the customer base. \\
$\mathbf{1 4}$ & $\begin{array}{l}\text { The sector, especially for BoP customers, is highly innovative, in context. Yet, how far the models are } \\
\text { exportable is uncertain. }\end{array}$ \\
\hline $\mathbf{1 5}$ & $\begin{array}{l}\text { Eko and Indusland Bank's business models appear sustainable, provided the rate of enrolment is } \\
\text { greater than the rate of customer loss, as their incomes improve. }\end{array}$ \\
\hline
\end{tabular}




\subsubsection{Combined Technological and Social Agendas}

India's m-payments SSI strives to include the poor and unbanked; the social justice agenda is important. Expansion constraints include the difficulties of marketing m-payments services to often-illiterate rural residents and the absence of $2 \mathrm{G}$-network connectivity in many rural areas. The institutional and regulatory environment in India promotes the social justice goal of enabling the bottom of the pyramid (BoP) consumers to become banked via m-payments. Regulations and institutional arrangements in India are supporting and driving m-payments innovation, firms are responding with appropriate technology, though as elsewhere in Indian economic development, infrastructure is a major constraint.

\subsubsection{Institutions Drive Innovation}

TIBCO, an US company that provides payment orchestration, believes that companies in emerging economies can move faster with new technologies because these countries have the legacy infrastructure of older technologies, and there are fewer government regulations than in developed economies. In 2008, the Reserve Bank of India (RBI) laid out a framework of operating guidelines for mobile banking transactions. In 2010, the RBI and Telecom Regulatory Authority of India (TRAI) announced a collaboration to create a standard regulatory environment for mobile banking transactions covering technology, security, business, regulatory and supervisory issues in addition to extending banking regulations to mobile banking and prescribed ways for banks and TeleCos to cooperate.

Banks that are licensed, supervised and physically reside in India are permitted to offer mobile banking products. Service providers and TeleCos can develop and launch customized applications for their customer base however the messaging system between application and banks is regulated. The mobile payments services framework involves the collaboration of banks, mobile payments service providers and mobile network operators (MNOs). Banks provide the basic service framework, ensuring compliance, risk management and settlement of funds. Mobile payments service providers are intermediaries providing the technology infrastructure MNOs provide the telecom infrastructure and connectivity to the customers.

The regulatory stance in India promotes innovation to achieve inclusion, accessibility and affordability, prescribing technology neutrality and interoperability; encapsulated in RBI's (2005) vision of an umbrella institution for all the retail payment systems in the country consolidating and integrating multiple systems into nation-wide uniform and standard business process for all retail payment systems and to facilitate an affordable payment mechanism to help financial inclusion. As a result, the National Payments Corporation of India (NPCI) was incorporated in 2008 overseeing all electronic retail payment systems, delivery channels, service providers numbers and technology solutions. As the CEO of an Indian solutions provider says:

So, let me put it this way: India has never prescribed banks to tie up necessarily with operators, or just the telecomm operators. If telecomm operators want to be in the State in India, they need the bank to provide cash out and other services, which are more, banking related. So, if they were to kind of operate a security framework, the multiple regulations out there in India, so that is what comes because you use the world banking correspondent or things like that.

This hub creates scale economies and the Interbank Mobile Payment Service (IMPS) making payment processes easier and simpler by stipulating real-time remittances over a national network and cardless cash ATM withdrawals. Additionally, IMPS includes TeleCos through the Unstructured Supplementary Services Data (USSD) platform in which all mobile customers are then able to access banking services simply by dialing a common USSD number irrespective of the Telco or the bank creating a standard process. Since banks are obliged by the Government to use NPCI protocols, B2B services are also standardized. Non-bank finance companies since 2007 seeking to issue pre-paid payment instruments are required to get NBI authorization, which is increasingly allowed for payments up to R 50,000 (i.e., £5,000). Pre-paid instruments can be used for all purchases or to store value in a 
bank account or credit card in a variety of closed, semi-closed or open systems, however, only registered banks can launch open mobile based prepaid payment instruments (mobile wallets and accounts).

\subsubsection{Innovative Firms and Business Models}

Semi-closed mobile wallets are proving attractive, for example Bharti Airtel's subsidiary Airtel Money launched a pilot initiative in Gurgaon, Delhi partnering with shops, restaurants and cinemas in the suburb, others such as ItzCash Cards followed. Since 2006, Banks can appoint business correspondents $(\mathrm{BC})$ to encourage banking services in rural areas. The $\mathrm{CEO}$ of a solutions provider describes the BCs a:

So, the banking correspondent is basically just an extension of a banking network, so instead of the brick and mortar bank branches you can, you know, reach and therefore be, putting the penetration of banking services. So, it would be anybody in the country, so one of them could be an operator, a mobile network operator because they have this traditional network but they only act on behalf of the bank. The consumer in this case is owned by the bank, so the operator or anybody else, third party, really provides the network from a distribution standpoint, for consumers to access banking services.

Agents, often associated with banks, recruit and provide no-frills savings accounts, deposits, withdrawals and remittances. Additionally, banks are recruiting in rural areas making partnerships with NGOs, self-help groups, micro-finance groups, owners of Kirana stores and individuals acting as intermediaries. This resulted in Technology providers such as Eko, FINO, and A Little World setting up non-profit arms to participate in branchless banking activities.

For example, Eko a financial services company, provides the back-end technology as well as a BC network for branchless no-frills m-payment services to the unbanked, accessible via mobile networks and retail shops, who in turn are paid a commission, with commissions on transactions accounting for $80 \%$ of Eko's revenue. Eko's model brings unbanked people to the banking network, using hundreds of small shop owners. Once a customer registers with Eko using a mobile number, the small kirana shop or pharmacy acting as an agent helps him/her open a bank account at the partnered bank. The agents pre-fund cash into accounts against which e-money is issued (eliminating debt risk) information which is transmitted over the phone network to Eko's servers, validating the transaction and account adjustments with instant confirmation. Since the entire transaction is digital, costs are low, provided volumes are high: a classic BoP business model. The Chief Marketing Manager of an Indian financial services firm elaborates on the aspect of the transaction when he discusses:

So when it is all electronic and you are dealing with just pure electronic stuff, the cost of the transaction can be low but we are dealing with a lot of cash and therefore the exchange of information is really what we have made really cheap; the transactions, the processing of financial transactions are still, and convenient, and easy, and in areas where say, for example, data directing is not available, which is a very large part of the country still, that does not have connectivity.

Indusland Bank's IndusMobile has a similar model targeting the urban poor making M2M cash transfers remittances, C2B payments or NPCI's Inter-bank Mobile Payment Service via mobile devices transmitting SMS messages authenticated and secured by a four-digit MPIN and two layer security authorizations. It allows cashless withdrawals convertible into cash within 24-hours for which agents take commission.

India's m-payments SSI include foreign players, for example, TIBCO a R\&D center developing mobile software. Induland Bank and Eko, who are social entrepreneurs; leveraging other social institutions to overcome infrastructural deficits by creating low-cost (frugal) business models that enhance financial exclusivity, utilizing domestic and international R\&D. 


\subsubsection{The Indian Government}

SSI governances in India's m-payments are heavily influenced by the state, in particular the financial inclusion agenda. These arrangements have led to the creation of sustainable business models serving the unbanked, however, this is at the cost of limiting innovation in the wider system by inhibiting entrants and slowing down the rollout of 3G. In context, Indian m-payments is highly innovative: leveraging other social institutions, enrolling 200 million unbanked users and services such as P2P financial transfers. The latter, in particular, is a key KYC demand currently met in India, but not in the UK. Provided transaction volumes continue to rise, India's m-payments SSI has created sustainable business models. The challenge is to alter the model as more people join the middle-classes and demand more sophisticated services noting that middle-class users yearning for $3 \mathrm{G}$ enabled services in cities are paying the price for the institutional pressure on the Banks and TeleCos to prioritize unbanked users.

\section{Discussion}

\subsection{Drivers of Innovation in the UK and Indian M-Payments Sectors}

TeleCos in the UK (Vodafone, O2 and EE) and India (Bharat, Tata Indicom, Reliance and AirTel) are being squeezed. Given the ubiquitous availability of banking, point-of-service (PoS) access and the Internet in the UK, it is understandable that the telecommunications network is considered a commodity product, necessary as a background partner but not new value-adding in the m-payments SSI. India's TeleCos occupy a more leading position in m-payments innovation, however, the strategic priorities are set by the state to extend the $2 \mathrm{G}$ network, thus, in India, state policy rather than TeleCos are drivers of innovation; at NPCI's behest intermediaries occupy the SSI's ideas space.

Indian Banks are in danger of occupying commodity service space, as holders of deposits and data, whereas the institutional arrangements in the UK enable entrants to become banks, retailers, branded companies in partnership with banks and credit card companies. Low $3 G$ reach in India coupled with strong regulation is inhibiting banks from being innovative e.g., in apps, m-wallets and NFC, whereas the UK Barclays case, demonstrates a bank being radically innovative (P2P transfers). From the viewpoint of unbanked non-customers, the SSI in India is innovative; however, intermediaries with NPCI's support drive innovations rather than TeleCos and Banks.

From the perspective of innovation ecosystem, technological innovation should be connected to business model development and target markets as a positive innovation flows and feedback loops [72]. Therefore, SSI is not just a technological innovation but requiring more cross-disciplinary applications and interactions with the users. Previous studies proposed the concept of open innovations based on the transfers across the boundaries of knowledge \& technology and different types of entrepreneurial cyclical dynamics, such as market open innovation by SMEs and start-ups, closed open innovation by big business, and social open innovation [73,74]. By comparing the practices of SSI in India and UK, Indian innovation is much more closed and less international than the UK. M-banking is cost effective, but, overall, India is much more customer oriented. At first sight this seems irrational given India's international success at back-office data manipulation (Infosys, Tata, Reliance) and the direct involvement of these companies in TeleCos. Regulatory constraints ( $2 \mathrm{G}$ expansion, bank restrictions, ownership restrictions) explain absence of international involvement in the Indian m-payments SSI, noting that firms such as TIBCO are also back-office service providers. In the UK, banks and TeleCos are internationalized, making the SSI more open to new ideas, however, because of the lack of system-wide standardization, product innovations thrive though processes inhibit interoperability [75]. Indian institutions oblige banks and TeleCos to work with intermediaries creating system-wide standards to support innovative services; in this sense, the Indian m-payments SSI is the more innovative, especially from the viewpoint of the unbanked population. The UK SSI meanwhile, with exceptions such as Barclays, is focusing upon cost-down innovations such as NFC and m-wallets, neither of which are radically new products. India's business models based around high-volume, 
low-cost services are more radical and far-reaching than the UK, where data transfer contracts accessed by look-alike apps dominates m-payments, perhaps understandably since many people prefer to do internet-banking at home and restrict m-payments to micro-payments.

\subsection{Innovation in the UK and Indian M-Payments Sector}

In terms of innovations, the potential of these m-payments SSIs to become global leaders, technology shifters, satisfied adopters or laggards relates to their innovation processes. The UK's regulatory environment enabling m-payments market entry, ICT infrastructure rolling out 4G and availability of m-wallets and NFC for nomadic micro-payments all suggest a highly innovative environment that (given the internationalization of its banks and TeleCos) could aspire to global leadership. However, many countries are protective of the banking system and may be techno-nationalistic [76] since control is important to economic development and stability. Thus, it is difficult to conceive that Barclays will become the dominant m-payments provider globally. Further, such a scenario presumes that bank(s) and TeleCo(s) joint-venture internationalization, when the evidence is that they cannot cooperate effectively at a national level. Far more likely is the internationalization of back-office m-payments systems, perhaps emulating, and possibly sourced, from the Indian firms successfully manipulating data and providing TeleCo services in India. Given low penetration of $4 \mathrm{G}$ and $3 \mathrm{G}$ in developing economies, technology-shifter appropriate or intermediate technologies may more successfully internationalize than m-wallets and NFC; at least in the short-term.

The importance of branding in sectors where consumer trust and recognition are important cannot be underestimated. By customer numbers, the Agricultural Bank of China (ABC) is the largest (320 million), followed by the Industrial and Commercial Bank of China (282) and Citigroup (200); RBS has 23 million; Baroda a similar number. ABC's customer base is equal that of iTunes and Amazon which enjoy, outside of China, much higher brand recognition. There lies the possibility that a disruptive player will enter the m-payments sector with a global standard to alter completely the nature of m-payments innovation.

Each of the Indian cases reveals a unique business model; the UK SSI is innovative, however not in business models, rather in channels (m-wallet, NFC, apps). Each SSI shows itself capable of generating radical and incremental innovations. An advantage of flexibility in business models is that as new coalitions come into being, the distribution of value in the chain can alter. UK business models are bank-centric or mobile network centric with more collaborative models ( $\mathrm{m}$-wallets and NFC growing in popularity) and independent operators (retailers etc.) in direct competition with banks and network providers. Again, the governances of the UK SSI have retarded the growth of collaborative models whilst the Indian system encourages them, although Indian business models have yet to achieve national (as opposed to regional) standards. It may be that the emergent collaborate UK business models become the dominant.

In comparing SSIs in their ability to achieve internationalization is possible, but difficult. Financial services embody cultural proclivities and are difficult to internationalize, though currency exchange and micro-payments may prove the exception. Barclays P2P transfer services are clearly capable of internationalization, the Indian systems less so; like M-Pesa it depends on nation communications networks and signals via texting. The EU Directives on m-payments are designed to encourage single-market internationalization but only via call-centers. Other countries' m-payments systems also struggle to internationalize: in the case of Japan because it is too advanced. Korea's Danal m-payments system is targeting other Asian Markets. The Chinese Government, like India's, has targets non-banked people in encouraging Alipay, China M-World (a m-wallet) and Monternet (a network billing micropayments system), SmartPay in China supports P2P transfers and is already rolling out in the Philippines. Third-party payments are the driver in the Chinese m-payments SSI. It seems unlikely, that either the UK products, confined to the EU, or the Indian products, confined to India, will rapidly internationalize, though in India's case, firms offering back-office support may join international consortia offer m-payments services. 


\section{Conclusions and Implications}

Despite being similar in many aspects, there are significant differences between the UK and India. They embody contrasting characteristics in terms of their socio-economic and cultural background. The UK represents a populated, developed economy with an occidental cultural heritage; whereas India typifies a populous, emerging economy with an Asian cultural heritage. Consequently, although, there are several differences between the UK and Indian service sector. For instance, the UK financial service sector is mature and dominated by large global players. Additionally, like many other developed countries, the UK has gone through a process of deregulating and privatizing the financial service sector. On the other hand, India has only recently emerged as a country of immense industrial power that is actively pursuing policies of economic liberalization and privatization. For banks, though, the question is no longer whether mobile banking and payments will be important and sustainable because they are innovative for all aspects of $\mathrm{m}$-financial services. To reap these opportunities, banks will have to overcome both internal and external challenges, noting, however, that the bigger obstacles such as the development of standards, the roll out of technologies, the adoption of services, how to work with new and emerging value chain partners, how to endorse new revenue sharing models that properly acknowledge each player's role in delivering mobile services are systemic, are thus largely beyond the control of banks or financial service firms individually. Furthermore, the road to any $\mathrm{m}$-services in the UK is fraught with risk as a combination of nascent technologies, unproven demand, fractured approaches, and the lack of standards and networks more so than in India.

In developed markets, the emphasis must be on speed of transaction, convenience and value, as many people have accounts where basic services like direct debits and standing orders already operate to the satisfaction to the customer. It is a different proposition when considering developing countries. The main distinction comes from how developing countries stack up in terms of existing private banking framework. However, in the future, cost will not be so big of an issue simply because mobile transcends the costs. Mobile remote payment has huge potential in markets where this infrastructure is scarce, as it enables two parties to send and receive payments or exchange funds using the mobile channel, irrespective of where they are located. This allows the transfer of funds or payment of a bill with nothing but a mobile handset and the payee's payment reference/phone number. The payment received from any such transaction can then be redeemed as airtime, goods or cash at selected merchants. The size and population density of these markets make them a very attractive proposition for $\mathrm{m}$-financial stakeholders.

A fundamental challenge identified in the UK is the lack of strong innovative specific institutions, specifically the regulative institutions for m-payment systems as a whole. While in India, poorly managed implementation of some of the regulative institutions has led to strengthening of cognitive institutions amongst firms as a consequent of regulation that includes a sense of disadvantage, helplessness and exploitation, and lastly, distrust of the government. Results in the UK have shown that certain firms are creating groups of alliances which involve more than two firms such as Weve; whereas in India, firms are forming individual alliances with other firms. Group alliances are more likely to involve communication across multiple partners and joint ventures with shared control, but it might also constrain the firms involved. Such constraints are likely to detract from innovation.

\section{Implications}

The implications for m-payments in many countries are far-reaching and evolutionary as such applications can be described as being almost disruptive innovations because their effects are life altering where changes in the way consumers go about their daily routines are increasing. For practitioners, the research is organized based on a set of factors. Practitioners should direct innovation and technological development towards creating better interoperability with users and merchants. Furthermore, findings indicate in which the business models of m-payment systems will need to evolve from limited proprietary solutions towards cooperation and standardized solutions in order for firms to succeed and become global players. 
The study emphasizes the importance of integrating firms' activity (including new product and service design) into integrated service systems since the particular nature of these systems for m-payments varies between contexts. For instance, demand-driven innovation influences the way products are manufactured to fit consumer needs. For innovative products that fulfil consumers demand to be successful, tight user-producer relationships must be established throughout the development process. Failures to form successful user-producer relationships may mean that developed products are not suitable or that end-users are not receptive to using them. Thus, there is reason to believe that India could be successful in creating a new service development at a lower price than the UK; especially within the business correspondent business model. Thus, existing theory needs to take into consideration the possibility that emerging market firms are perhaps more innovative than developed countries, and consequently, future research should address this with caution.

As new technologies, products and business models develop, new markets and market failures may emerge requiring changes to the existing regulatory framework. The research notably finds that the impact of regulation on innovation is influenced by the way in which new proposals are designed, implemented and enforced. Evidence shows that policy makers and regulators are more likely to support innovation or avoid hampering it. Yet, they provide businesses with some flexibility as to how desired policy outcomes are delivered, clearly inform businesses about future changes in the regulatory framework well in advance, specify desired outcomes which cannot be easily achieved using existing technologies and business practices, stipulate clear requirements, reducing the possibility of misinterpretation, impose minimum compliance costs, and complement other government market-based and regulatory-based policies that promote innovation. A consensus view in literature concerning the role of governments is that they need to provide the economic and legal institutional framework for businesses. For example, in the context of emerging economies, emphasis is placed on government responsibility where institutional conditions either enable or hinder entrepreneurship, and the regulatory protection of vulnerable consumers. However, government intervention should not duplicate nor crowd out firms, but offer a balance in both countries.

In regards of the relationship between regulation and innovation, this relationship is ambiguous when it comes to such issues as competition. Pro-competitive regulation that prohibits anti-competitive behavior encourages innovation by reducing barriers to entry for new, more innovative firms, and by allowing firms to choose more freely the strategies and business models which best facilitate innovation. Yet, the same regulation may restrict innovation by preventing businesses from collaborating closely at the R\&D stages, preventing certain organizational structures or the formation of some agreements which could facilitate the transfer of knowledge and technologies.

There are several important repercussions for how innovation in developing countries is perceived. It is unknown to the extent to which the innovation processes discussed here apply to other high-tech fields. More research on the process of innovation in other emerging sectors as well as further exploration of innovation in developing countries is needed to expand alternative models to those currently in the literature. Thus, one can conclude instead that innovation in emerging fields that have yet to reach their technological maturity is just as strong in developing countries as compared to developed countries. Furthermore, innovation happens in developing countries through processes that are more complex than originally conceptualized.

Author Contributions: Conceptualization, H.W.; Data curation, H.W.; Formal analysis, S.L.; Investigation, H.W., S.L. and M.-R.Y.; Supervision, M.-R.Y.; Writing—original draft, S.L.; Writing-review and editing, S.L. and M.-R.Y.

Funding: This research received no external funding.

Conflicts of Interest: The authors declare no conflict of interest. 


\section{Appendix A}

Table A1. Interviews and surveyed groups.

\begin{tabular}{cccccc}
\hline No. & Company & Industry & Country of Origin & Public or Private & $\begin{array}{c}\text { Countries of } \\
\text { Operation for Service }\end{array}$ \\
\hline $1 \mathrm{~A}$ & $\begin{array}{c}\text { National Payments } \\
\text { Corporation of India (NPCI) }\end{array}$ & Finance & India & Public & India \\
\hline 2 B & Atom Technologies & Software Technology & India & Private & India \\
\hline 3C & Eko Indian Financial Services & Finance & India & Private & India \\
\hline 4D & Mahindra Comviva & Telecommunications & India & Private & Global \\
\hline $5 \mathrm{E}$ & Induslnd Bank & Finance/Banking & India & Private & India \\
\hline 6F & HDFC & Finance/Banking & India & Public & India \\
\hline $7 \mathrm{G}$ & Idea Cellular & Telecommunications & India & Public & India \\
\hline 8H & CITI Group & Finance/Banking & US & Public & Global \\
\hline $9 \mathrm{I}$ & iKaaz & Software Technology & India & Private & Global \\
\hline $10 \mathrm{~J}$ & Beam Money & Software Technology & India & Public & India \\
\hline $11 \mathrm{~K}$ & Standard Charter & Finance/Banking & UK & Public & Global \\
\hline $12 \mathrm{~L}$ & Nokia Siemens Networks & Telecommunications Equipment & Finland & Public & Global \\
\hline $13 \mathrm{M}$ & MH Invent & Software/Security & UK & Private & UK/Europe \\
\hline $14 \mathrm{~N}$ & Tesco Bank & Finance/Banking/Insurance & UK & Private & UK \\
\hline $15 \mathrm{O}$ & TIBCO Software Limited & Computer Software & US & Public & Global \\
\hline $16 \mathrm{P}$ & Monitise Group & Technology/Services & UK & Public & Global \\
\hline $17 \mathrm{Q}$ & GSM Association & Trade Association for Telcos & UK & Private & Global \\
\hline $18 \mathrm{R}$ & Royal Bank of Scotland & Finance/Banking & UK & Public & Global \\
\hline $19 \mathrm{~S}$ & Sainsbury Bank & Finance/Banking & UK & Public & UK \\
\hline $20 \mathrm{~T}$ & Lloyds TSB & Finance/Banking & UK & Public & UK \\
\hline $21 \mathrm{U}$ & Barclays & Finance/Banking & UK & Public & UK \\
\hline
\end{tabular}

\section{References}

1. Chang, H.J. Institutional Change and Economic Development; Anthem Press: New York, NY, USA, 2007.

2. Gartner. Gartner Says Worldwide Mobile Payment Transaction Value to Surpass \$171.5 Billion. 29 May 2012. Available online: http://www.gartner.com/newsroom/id/2028315 (accessed on 2 November 2013).

3. Reserve Bank of India. M-Banking in India-Regulations and Rationale. 2012. Available online: http://www.rbi.org.in/scripts/BS_SpeechesView.aspx?id=681 (accessed on 3 November 2013).

4. Crabbe, M.; Standing, S.; Karjaluoto, H.; Standing, C. An adoption model for mobile banking in Ghana. Int. J. Mob. Commun. 2009, 7, 515. [CrossRef]

5. Gu, J.C.; Lee, S.C.; Suh, Y.H. Determinants of Behavioural Intention to Mobile Banking. Expert Syst. Appl. 2009, 36, 11605-11616. [CrossRef]

6. Demirguc-Kunt, A.; Klapper, L.; Randall, D. The Global Findex Database Financial Inclusion in India; The World Bank: Washington, DC, USA, 2013; Available online: http://siteresources.worldbank.org/ EXTGLOBALFIN/Resources/8519638-1332259343991/N8india6pg3.pdf (accessed on 20 February 2014).

7. Mallat, N. Exploring Consumer Adoption of Mobile Payments-A Qualitative Study. Sprouts Work. Pap. Inf. Syst. 2006, 6, 44. [CrossRef]

8. Shon, T.H.; Swatman, P.M.C. Identifying effectiveness criteria for Internet payment systems. Internet Res. 1998, 8, 202-218. [CrossRef]

9. Siau, K.; Sheng, H.; Nah, F.; Davis, S. A qualitative investigation on consumer trust in mobile commerce. Int. J. Electron. Bus. 2004, 2, 283-300. [CrossRef]

10. Jayawardhena, C.; Foley, P. Overcoming constraints on electronic commerce: Internet payment systems. J. Gen. Manag. 1998, 24, 19-35. [CrossRef]

11. Ogle, R. Smart World; Harvard Business School Press: Cambridge, MA, USA, 2008.

12. Breschi, S.; Malerba, F. Sectoral Innovation Systems: Technological Regimes, Schumpeterian Dynamics and Spatial Boundaries; Edquist, C., Ed.; Systems of Innovation Pinter: London, UK, 1997; pp. 130-156. 
13. Geels, F.W. Sectoral systems of innovation to socio-technical systems: Insights about dynamics and change from sociology and institutional theory. Res. Policy 2004, 33, 897-920. [CrossRef]

14. Trist, E. Referent organisations and the development of inter-organisational domains. Hum. Relat. 1951, 36, 269-284. [CrossRef]

15. Varieties of Capitalism; Hall, P.A.; Soskice, D.W. (Eds.) OUP: Oxford, UK, 2001.

16. Casper, S. Creating Silicon Valley in Europe; OUP: Oxford, UK, 2007.

17. Scott, W.R. Institutions and Organisations; SAGE: London, UK, 1995.

18. Kay, J. The Truth about Markets; Penguin: London, UK, 2004.

19. Gladwell, M. The Tipping Point: How Little Things Can Make a Big Difference; Little, Brown and Co.: Boston, MA, USA, 2006.

20. Hughes, T.P. Networks of Power: Electrification in Western Society, 1880-1930; The Johns Hopkins University Press: Baltimore, MD, USA, 1983.

21. Malerba, F. Sectoral systems of innovation and production. Res. Policy 2002, 31, 247-264. [CrossRef]

22. Lave, J. Situated learning in communities of practice. In Perspectives on Socially Shared Cognition; Resnick, L.B., Levine, J.M., Teasley, S.D., Eds.; American Psychological Association: Washington, DC, USA, 1993; pp. 63-82.

23. Nardi, B.A. Studying context: A comparison of activity theory, situated action models, and distributed cognition. In Context and Consciousness: Activity Theory and Human-Computer Interaction; Nardi, B.A., Ed.; The MIT Press: London, UK, 1996; pp. 69-102.

24. Bourdieu, P. Systems of education and systems of thoughts. In Knowledge and Control; Young, F.D., Ed.; Collier-Macmillan: London, UK, 1997; pp. 189-207.

25. Herrmann, A.; Peine, A. When 'national innovation system' meet 'varieties of capitalism' arguments on labour qualifications: On the skill types and scientific knowledge needed for radical and incremental product innovations. Res. Policy 2011, 40, 687-701. [CrossRef]

26. Østergaard, C.R.; Timmermans, B.; Kristinsson, K. Does a different view create something new? The effect of employee diversity on innovation. Res. Policy 2011, 40, 500-509. [CrossRef]

27. Schumpeter, J.A. Business Cycles: A Theoretical, Historical and Statistical Analysis of the Capitalist Process; McGraw-Hill: London, UK, 1939.

28. Park, H. Technology convergence, open innovation, and dynamic economy. J. Open Innov. Technol. Mark. Complex. 2017, 3, 24. [CrossRef]

29. Nelson, R.R.; Winter, S. An Evolutionary Theory of Economic Change; Harvard University Press: Boston, MA, USA, 1982.

30. Vargo, S.L.; Lusch, R.F. Evolving to a New Dominant Logic for Marketing. J. Mark. 2004, 68, 1-17. [CrossRef]

31. Vargo, S.L.; Lusch, R.F. Service-dominant Logic: Continuing the Evolution. J. Acad. Mark. 2008, 36, 1-10. [CrossRef]

32. Bitner, M.; Ostrom, A.; Morgan, F. Service blueprinting: A practical technique for service. California Management Review. 2007, 50, 66-94. [CrossRef]

33. Amit, R.; Zott, C. Value creation in E-business. Strateg. Manag. J. 2001, 22, 493-520. [CrossRef]

34. Chesbrough, H. Business model innovation: it's not just about technology anymore. Strategy Leadersh. 2007, 35, 12-17. [CrossRef]

35. Yun, J. How do we conquer the growth limits of capitalism? Schumpeterian Dynamics of Open Innovation. J. Open Innov. Technol. Mark. Complex. 2015, 1, 17. [CrossRef]

36. Patra, S.; Krishna, V. Globalization of R\&D and open innovation: Linkages of foreign R\&D centers in India. J. Open Innov. Technol. Mark. Complex. 2015, 1, 7.

37. Dweck, C.S. Mindset: The New Psychology of Success; Random House: New York, NY, USA, 2006.

38. Granovetter, M. The strength of weak ties. Am. J. Sociol. 1973, 78, 1360-1380. [CrossRef]

39. Chesbrough, H. Business model innovation: Opportunities and barriers. Long Range Plan. 2010, 43, 354-363. [CrossRef]

40. McGrath, R. Business Models: A Discovery Driven Approach. Long Range Plan. 2010, 43, 247-261. [CrossRef]

41. Demil, B.; Lecocq, X. Business Model Evolution: In Search of Dynamic Consistency. Long Range Plan. 2010, 43, 227-246. [CrossRef]

42. Smith, W.K.; Binns, A.; Tushman, M.L. Complex business models: Managing strategic paradoxes simultaneously. Long Range Plan. 2010, 43, 448-461. [CrossRef] 
43. Turban, E.; King, D.; Lee, J. Electronic Commerce 2006; Pearson Educational International: Upper Saddle River, NJ, USA, 2006.

44. Laukkanen, T. Internet vs. mobile banking: Comparing customer value perceptions. Bus. Process Manag. J. 2007, 13, 788-797. [CrossRef]

45. Karnouskos, S.; Fokus, F. Mobile Payment: A journey through existing procedures and standardization initiatives. IEEE Commun. Surv. Tutor. 2004, 6, 44-66. [CrossRef]

46. Dahlberg, T.; Mallat, N.; Ondrus, J. Past, present and future of mobile payments research: A literature review. Electron. Commer. Res. Appl. 2008, 7, 165-181. [CrossRef]

47. Bryman, A.; Bell, E. Business Research Methods; Oxford University Press: Oxford, UK, 2007.

48. Rabinow, P.; Sullivan, W.M. Interpretive Social Science, 2nd ed.; University of California Press: Berkeley, CA, USA, 1985.

49. Yanow, D. Conducting Interpretive Policy Analysis; Sage: Thousand Oaks, CA, USA, 2000.

50. Hewitt-Taylor, J. Use of constant comparative analysis in qualitative research. Nurs. Standard. 2001, 15, 39-42. [CrossRef]

51. Ambert, A.; Adler, P.A.; Adler, P.; Detzner, D.F. Understanding and evaluating qualitative research. J. Marriage Fam. 1995, 57, 879-893. [CrossRef]

52. Schiffman, L.G.; Kanuk, L. Consumer Behaviour; Prentice Hall: Upper Saddle River, NJ, USA, 2000.

53. Tvede, L.; Ohnemus, P. Marketing Strategies for the New Economy; John Wiley \& Sons: Chichester, UK, 2001.

54. Saunders, M.; Lewis, P.; Thornhill, A. Research Methods for Business Students, 4th ed.; Pearson Education: Harlow, UK, 2007.

55. Eisenhardt, K.M. Building Theories from Case Study Research. Acad. Manag. Rev. 1989, 14, 532-550. [CrossRef]

56. Hartley, J.F. Case studies in organizational research. In Qualitative Methods in Organizational Research; Cassell, C., Symon, G., Eds.; Sage: London, UK, 1994; pp. 209-229.

57. Yin, R. Applied Social Research Methods Series. In Case Study Research: Design and Methods; Sage: Thousand Oaks, CA, USA, 1994; Volume 5.

58. Eisenhardt, K.; Graebner, M. Theory Building From Cases: Opportunities and Challenges. Acad. Manag. 2007, 50, 25-32. [CrossRef]

59. Frederickson, J. Strategic Process Research: Questions and Recommendations. Acad. Manag. Rev. 1983, 8, 565-575. [CrossRef]

60. Llewelyn, S. What counts as "theory" in qualitative management and accounting research? Introducing five levels of theorizing. Account. Audit. Account. J. 2003, 16, 662-708. [CrossRef]

61. Bourgeois, L.J. III Toward a Method of Middle Range Theorizing. Acad. Manag. Rev. 1979, 4, $443-447$. [CrossRef]

62. Peterson, M.F. Embedded Organisational Events: The Units of Process in Organisation Science. Organ. Sci. 1998, 9, 16-33. [CrossRef]

63. Pauwels, P.; Matthyssens, P. The Architecture of Multiple Case Study Research in International Business. In Handbook of Qualitative Research Methods for International Business; Marschan-Piekkari, R., Welch, C., Eds.; Edward Elgar: Cheltenham, UK, 2004; pp. 125-143.

64. Gummesson, E. Quality Dimensions: What to Measure in Service Organizations. In Advances in Services Marketing and Management; Swartz, T., Bowen, D.E., Brown, S.W., Eds.; JAI Press: Greenwich, CT, USA, 1992; Volume 1, pp. 177-205.

65. Elliott, J. Using Narratives in Social Research; Sage: London, UK, 2005.

66. Castells, M. Communication Power; Oxford University Press: Oxford, UK, 2009.

67. Ahonen, T. m-Profits; Wiley: Chichester, UK, 2006.

68. Clemons, E.K. Business models for monetizing Internet applications and web sites: Experience, theory and predictions. J. Manag. Inf. Syst. 2009, 26, 15-41. [CrossRef]

69. Ondrus, J.; Lyytinen, K. Mobile payments market: Towards another clash of the Titans? In Proceedings of the 10th International Conference on Mobile Business, Como, Italy, 20-21 June 2011; pp. 166-172.

70. Whitley, R. Developing innovative competences: The role of institutional frameworks. Ind. Corp. Chang. 2002, 11, 497-528. [CrossRef] 
71. Godschalk, H.; Krueger, M. Why e-money still fails-Chances of e-money within a competitive payment instrument market. In Proceedings of the Third Berlin Internet Economics Workshop, Berlin, Germany, 26-27 May 2000.

72. Yan, M.R.; Chien, K.M.; Hong, L.Y.; Yang, T.N. Evaluating the collaborative ecosystem for an innovation-driven economy: a systems analysis and case study of science parks. Sustainability 2018, 10, 887. [CrossRef]

73. Yun, J.J.; Won, D.; Park, K. Dynamics from open innovation to evolutionary change. J. Open Innov. Technol. Mark. Complex. 2016, 2, 7. [CrossRef]

74. Yun, J.J.; Won, D.; Park, K. Entrepreneurial cyclical dynamics of open innovation. J. Open Innov. Technol. Mark. Complex. 2018, 28, 1151-1174. [CrossRef]

75. Utterback, J.; Abernathy, W. A dynamic model of process and product innovation. Omega 1975, 3, 639-656. [CrossRef]

76. Ostry, S.; Nelson, R.R. Techno-Nationalism and Techno-Globalism: Conflict and Co-Operation; Brookings Institution: Washington, DC, USA, 1995.

(C) 2019 by the authors. Licensee MDPI, Basel, Switzerland. This article is an open access article distributed under the terms and conditions of the Creative Commons Attribution (CC BY) license (http://creativecommons.org/licenses/by/4.0/). 